\title{
Eszterházy Károly püspök emlékezete Egerben 1925-ben
}

\section{A káptalani gyűlés}

„Eger városán kivül vajmi kevesen ismerik már Esterházy püspök nevét, söt Egerben is beh sokan vannak, akik nem tudják az Esterházy név jelentöségét!'” - írta Angyal Lajos az egri római katolikus fiú felső kereskedelmi iskola tanára 1925 márciusában. A tudósító éppen ezért lelkesen dicsérte Szmrecsányi Miklós müvészettörténész Eger és környéke részletes útikalauza címü könyvecskéjét, ${ }^{2}$ amelyben többször szerepel a föpap neve. Azonban talán nem is a turistáknak szóló szerény útikönyv, hanem ez a recenzió volt az, ami felkeltette az egriek figyelmét. Már itt le kell szögeznünk, hogy a Horthy-korszakban Egerben is a püspök nevét leggyakrabban - az élő rokonokra való tekintettel - Esterházy és nem Eszterházy alakban írták.

A következő tanulmány azokra a kérdésekre keresi a választ, hogy miért 1925ben kezdődött el a Líceumot építő mecénás tiszteletének felelevenítése, és a két világháború között Egerben milyen aktualitása és üzenete volt a hagyományok ápolásának és a kultusznak.

Angyal Lajos Egri csillagok címü tárcája azért is figyelemre méltó volt, mert az Egri Népújság címoldalán Dobó István mellé az „egri csillagok”, vagyis a hősök közé helyezte az egykori egyházfőt is. Szerinte Eszterházy püspök volt az, aki a vár pusztulásnak indult köveiből - szó szerint - új erődítményt épített, így a tudományok és művészetek fellegvárának a kapitánya lett. Ö a törökellenes háborúk után már békében dolgozhatott, és a tudás térhódításának nyitott kaput. Megváltoztatta Eger városképét, írta Angyal, ezért a „magyar Spártából” „magyar Athén” lett, ahol otthonra leltek a múzsák, és nagy lendülettel kezdődött meg az alkotó munka. Monumentális alkotásai 150 év után is büszke hirdetői voltak a magyarság élni akarásának - írta a szerző, ami szerinte az 1920-as trianoni béke után mások számára is példamutató cél lehet. Tulajdonképpen annak a nemzeti kulturális újjászületésnek

1 Egri Népújság, 1925. március 14. 1.

2 Szmrecsányi Miklós: Eger és környéke részletes kalauza, (24 képpel, 1 alaprajzzal, 1 mümelléklettel és 1 térképpel) Részletes helyi kalauzok 4. Szerk. Thirring és Vigyázó, Turistaság és Alpinizmus kiadása, Bp. 1925. 
az előfutárai közé sorolta a püspököt, amelyről éppen az 1920-as évek elején kezdett programszerűen beszélni Klebelsberg Kunó vallás- és közoktatási miniszter. Amint a szatmári béke után is elkezdődött egy lassú regenerálódás, a trianoni béke után is fokozatosan konszolidálódtak a körülmények. Az ismertető felidézte a mecénás föpap emlékét, majd azt hangsúlyozta, hogy az útikalauz sokkal több, mint egy ismeretterjesztő füzet, mert szerzője tudományos igényességgel és Eger iránti szeretetből írta. Szmrecsányi Miklós, az egri érsek öccse 1899-ben költözött Egerbe, ahol valóban évtizedekig kutatta, ismertette és óvta a város műemlékeit. Angyal Lajos tehát azt tartotta a füzet legnagyobb értékének, hogy felhívta a figyelmet Eszterházy püspök művészettörténeti örökségére. „A harcterek kemény hadvezére (ti. Dobó István) mellett erös vonásokkal rajzolódik elénk a kultúráért vivott harc vezérének, Esterházy püspöknek hatalmas alakja, akinek nagy gondolata döntö diadalra viszi Egert."' folytatta a méltatást, majd Szmrecsányi írását remekbe készült „költeménynek” és a püspökre utalva „egy diadalmas lélek apotheózisának” nevezte.

Néhány hónappal később az egri központi (vagyis a városi) papság 1925. május 4-én tartotta meg a kánon szerinti tavaszi gyűlését. A napot Szmrecsányi Lajos érsek tűzte ki, ő volt az elnök, és az összejövetelt érseki palotában tartották meg. Nagy jelentőséget adott az eseménynek, hogy éppen azon a napon 200 éve jegyezték be a pozsonyi kereszteltek anyakönyvébe Eszterházy Károly születési adatait. ${ }^{4}$

Az egri érsek azért választotta ezt a napot, hogy - ha szük körben is, de - megünnepelhesse „évlapjainkban kitörölhetetlen betükkel bevésett nagy elödének emlékét". A gyülés egyetlen témája az ő előadása volt, amely részletesen bemutatta előfutára és példaképe jellemét, összefoglalta, ami róla a köztudatban fönnmaradt, hogy a nevezetes évfordulón úgymond: "felmelegedjenek az iránta különben is hálával telt szivek, s a mai nemzedék odahangoltassék, hogy azt a tiszteletet és hálát, melyet ma még a név is ébren tart, átháritsa a jövö nemzedékre."

Az érsek arra is emlékeztette hallgatóit, hogy Eger városa, amely Eszterházy püspök munkájának és alkotásainak fö színtere volt, fôpásztori és földesúri áldozataiért cserében minden más településnél nagyobb hálára van kötelezve. Ezt a kötelességét azonban a város elhanyagolja, mert még azt a városfejlesztésért kifejtett régi gesztust is elfeledte, hogy az általa adományozott belső területet halála után róla nevezték el Károlyvárosnak. Ugyanakkor Szmrecsányi elismerte, hogy elődje elutasította a dicséretet, és eltérően a 18. századi gyakorlattól műveit nem engedte a címerével díszíteni, mert nagylelkủen és önzetlenül szolgálta Istent és a hazáját. Szerinte

3 Egri Népújság, 1925. március 14. 1.

4 Esterházy Károly gróf emlékezete, Érsek fópásztorunk beszéde Esterházy egri püspök születésének kétszázadik évfordulója alakalmával. Egri Egyházmegyei Közlöny, 1925. május 15. 69.

5 Egri Népújság, 1925. május 5. 1. 
azonban az utókornak kötelessége, hogy megköszönje neki áldozatait, és tisztelettel emlékezzen rá. Az érsek méltó akart maradni a püspökhöz, mert a fökáptalannal együtt a Líceumot a kor korszerü igényeinek megfelelően folyamatosan és külső segítség nélkül is fenntartotta, és kőbe kívánta vésni, hogy kinek köszönheti Eger és Magyarország ezt a hatalmas intézményt.

"Jeltelen a mi líceumunk, s ha ma még Károly püspök szól belöle, ki tudja, nem jö-e oly idö, mikor már nem lesz ember, aki a nagyszerü alkotással az ö nevét hozza kapcsolatba - mondta az érsek megjósolva hogy elhalványul majd az építtető neve. - Köbe kell azért vésni ott az alkotó nagy nevét, hogy ne csak a történetíró tudja, ki adta ezt a kincset Egernek és a hazának. Ma az ö születésének kétszázadik emléknapján kegyeletes érzelmekkel vállalom azt a feladatot magamra, egyszersmind az elözetes eszmecsere után fớkáptalanommal, merem az egész épület müszaki helyreállitását ugyanez alkalomból felvállalni, s e gyülésböl Dr. Wälder Gyula tanárt az elömunkálatokkal megbizni bizton állitva hogy a Méltóságos Fökáptalan a már eddig is kilátásban lévö támogatással amint más téren is szokta oldalam mellett lesz Károly püspök hagyatékának megörzése érdekében felvállalt munkámban."

Az igazsághoz hozzátartozik, hogy 3 hónappal korábban, 1925. január 31-én óriási, 7-es erősségü földrengés rázta meg Eger városát és környékét. ${ }^{8}$ A tudósítások és kárfelmérések szerint ekkor komolyan megsérült a Líceum épülete is, ahol iskolákon kívül könyvtár, múzeum volt elhelyezve. Az ősi épületnek különösen a keleti és a déli oldalát viselte meg a rázkódás, még a vastag falakon is jól látható és hosszú repedések keletkeztek, azonkívül a II. emeleti folyosó végig megrepedt. Wälder Gyula építészmérnök ezért a Mủemlékek Országos Bizottságának megbízásából már február első napjaiban Egerbe érkezett, hogy megszemlélje, mely műemlékek mekkora kárt szenvedtek, és hogy helyreállításukhoz milyen intézkedésekre van szükség. ${ }^{9}$ A jubileum és az újjáépítés tehát véletlenül egybeesett.

Wälder Gyula 1925 decemberében Budapesten, a mérnöki kamara dísztermében Eger város barokk épitkezései a XVIII. században címmel tartott előadást, amelyben művészeti szempontból mutatta be Eger történelmi műemlékeit, és az egyes épületek értékét emelte ki. Különösen a XVIII. század nagy püspökeit és kanonokjait dicsérte, akik művészi ízlésükkel és áldozatkészségükkel megadták Egernek városi

6 Wälder Gyula (1884-1944) építész, egyetemi tanár, az MTA tagja. „Egerben kifejtett munkásságával (pénzügyigazgatóság, posta, polgári iskola, Korona Szálló építése, Líceum és a minorita templom restaurálása stb.) elősegítette, hogy a város megőrizze barokk jellegét." - Magyar életrajzi lexikon 3. https:/www.arcanum.hu/en/online-kiadvanyok/Lexikonok-magyar-eletrajzi-lexikon-7428D/w7870D/walder-gyula-787D9/, letöltés 2018. ápr. 05.

7 Egri Egyházmegyei Közlöny, 1925. május 15. 74-75.

8 Egri Népújság, 1925. február 1. 1.

9 Uo. 
karakterét, és akiknek méltó utóda volt Szmrecsányi érsek, aki Eszterházy püspök nagy művének restaurálását rendelte el. Megemlékezett Szmrecsányi Miklósról is, akinek műízléssel párosult fáradhatatlan munkássága visszaadta Eger patináját. Wälder Gyula ugyanezt az előadást az egrieknek is bemutatta az egri Katolikus Körben 1926 februárjában. A budapesti előadáson egyébként megjelent dr. Nagy János kanonok egri nemzetgyülési képviselő is. ${ }^{10}$

Úgy tünik, sikerült a nagy barokk foopap nevét felidézni, mert hamarosan már egy aktuálpolitikai kommentárban szerepelt. 1925 május 21-22-én tartották ugyanis a budapesti törvényhatósági választásokat, amelyen kissé nőtt a szociáldemokraták népszerűsége, amit Egerben meglehetősen szenvedélyesen kommentáltak: „.. . a keresztény nemzeti gondolatot azonban itt kikezdeni ne merje senki, mert Esterházy püspök városa igaz magyar hüséggel, tántorithatatlanul kitart e gondolat mellett és szeretettel szorítja azt szivéhez. Jaj, volna annak, aki hozzányúlni merészelne!"'II Nagyon ijesztő lehetett ugyanis egyesek számára, hogy 1925-ben már 52 szociáldemokrata tagja lett a fővárosi testületnek. Ez a gondolat tömören kifejezte, hogy Egerben a helyi politikusok a Horthykorszakban a híres püspök örökségének mely részét tartották fontosnak.

Ezután 1925. szeptember 22-én Eger város képviselőtestülete rendkívüli közgyülést tartott, ahol még a tervezett vízvezeték kapcsán is elhangzott a püspök neve. Elsőként az érseket képviselő Subik Károly kanonok, pápai prelátus szólalt fel, mert azt híresztelték, hogy a foopap ellenzi a vízvezeték kiépítését. „... mindenki tudja, hogy öexcellenciája nagy elödjének, Esterházy püspöknek nyomdokain halad és; ha nem is tudott megvalósitani annyit, mint a dicsö elöd, az tisztán az újabb idök nehéz helyzetében találja az okát. "'2 Ez az indoklás pedig azt árulta el, hogy 1925-ben az egri érsek helyettese szerint példaképének tekintette a püspököt, és az eredeti barokk alkotásokat neobarokk emlékekkel kívánta gyarapítani.

Végül 1929 áprilisában csendben leplezték le Eszterházy püspök emléktábláját, ami a helyreállítás utolsó eseménye volt. A hatalmas ruskicai márványlap a Líceum építési adatait örökítette meg, a püspök carrarai márványból faragott médaillon arcképét pedig a híres Zala György készítette el Tischler Antal rézmetszete alapján. A felújítás három évig tartott, és egri mesterek is kivették belőle a részüket a tekintélyes építési vállalkozó Nagy testvérek mellett, akik lassan és pontosan végezték el az eredeti párkányok, konzolok, ablakkeretek kibontását valamint felújítását. „S ha az érseki líceum egymagában is elegendo" jelentöségü lenne arra, hogy Egernek hazai városaink között kiváló helyet biztositson, a reá forditott nagy áldozat az egész

10 Egri Népújság, 1925. december 22. 3.

11 Uo. 1925. május 24. 1.

12 Uo. 1925. szeptember 23. 2. 
országnak egyik legremekebb, egyedülálló müemlékét teljes értékének magaslatára emelte. "'33 Eszerint volt, aki a helyreállítás jelentőségét felépítéshez hasonlította.

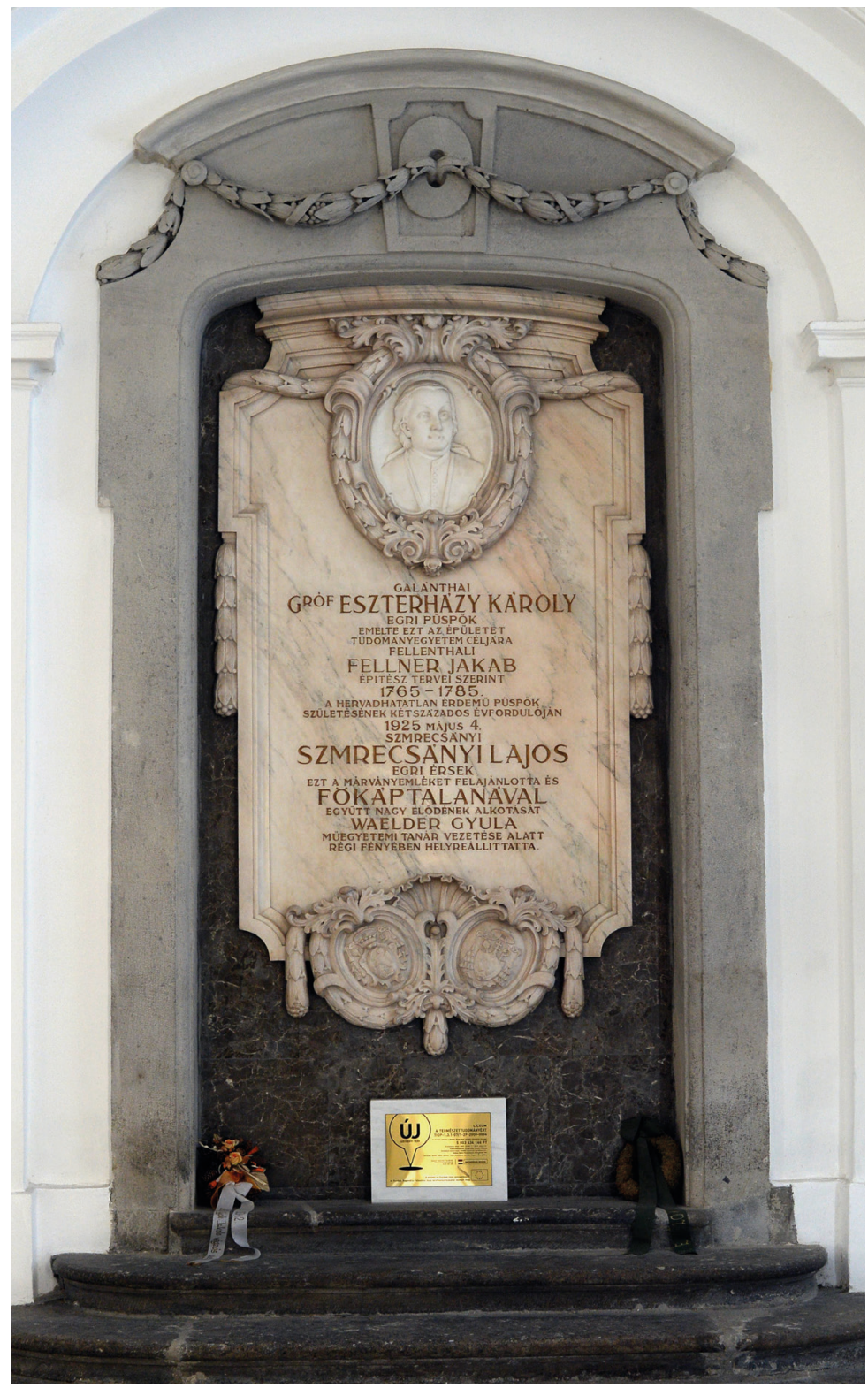

1. kép: Az 1929-ben leleplezett emléktábla (Szántó György felvétele)

13 Uo. 1929. április 28. 1. 


\section{A Gárdonyi Géza Társaság megemlékezése}

A tiszteletadás másik módja az volt, hogy 1925 szeptemberében az egri Gárdonyi Géza Irodalmi Társaság ${ }^{14}$ alelnöke, dr. Molnár Kálmán ${ }^{15}$, az érseki jogakadémia tanára jelentős összeget ajánlott fel egy történelmi téma kidolgozására a következő hirdetéssel: „Írassék meg Eger nagynevü püspökének, Esterházy grófnak élete, önálló forráskutatások alapján. Jutalma 2.000.000 korona. ${ }^{16}$ A jeligés levéllel ellátott, gépirással másolt pályamüvek 1927. január 1-ig adandók be a Gárdonyi Társaság elnökségének. (Eger, ciszterci gimnázium). A nyertes mü a szerzö tulajdona marad, esetleges kiadáshoz azonban a Gárdonyi Társaság hozzájárulása kikérendö. A Gárdonyi Társaság elnöksége. ”A püspök életrajza azonban 1926-1928 között sem készült el. ${ }^{17}$ Októberben dr. Kürti Menyhért ${ }^{18}$ ciszterci szerzetes tanár, tankerületi igazgató, a Gárdonyi Társaság elnöke az egyesület őszi programjairól nyilatkozott, és bejelentette, hogy Eszterházy Károly püspök emlékének is hódolni fognak. „Tervbe vette a Társaság, hogy ebben az évben, mint jubiláns esztendöben, Esterházy Károly egri püspök emlékét megörökitendö, diszközgyülést tart, melynek egyik szereplöjéül Szmrecsányi Miklós miniszteri tanácsos urat sikerült megnyernem. Az Esterházy-diszközgyülésre már nagyban folynak az elökészületek, hogy az ünnep minden tekintetben méltó legyen az egykori egri püspök halhatatlan nagy nevéhez." ${ }^{\prime \prime}$

A közgyűlés napján egy Veterán nevủ szerző Hösöket ünneplünk című írásában odáig ment, hogy különös módon az 1914 decemberében Limanowa mellett diadalt arató magyar katonák és Eszterházy püspök között vont párhuzamot. A püspököt azért állította a katonák mellé, mert szerinte főnemes létére ő is tudott olyan igénytelenül élni, csendben szenvedni, temérdek áldozatot hozni a közjóért, mint az első világháború hősei. „Megértjük-e a büszke falaknak áldozatkészségre tanitó, bölcs beszédét - kérdezte Veterán - s hiven fogjuk-e követni az utat, melyet a magyar Athén, prófétalelkü föpásztora alapitotta iskolákban tártak föl elöttünk mestereink?" ${ }^{20}$

Ilyen őszi előzmények után ünnepelte a püspök születésének bicentenáriumát Eger rendezett tanácsú város képviselőtestülete a Gárdonyi Társaság közreműködésével 1925. december 13-án vasárnap a városháza nagytermében nyilvános díszközgyülés

14 1923-1945 között működő egri kulturális egyesület.

15 Molnár Kálmán (1881-1961) jogász, egyetemi tanár, az MTA tagja, 1907-1925 között az egri jogakadémia tanára.

161925 elején 2 millió koronáért egy új bőrkabátot, kerékpárt vagy egy használt varrógépet lehetett vásárolni a helyi újság szerint.

17 Uo. 1927. szeptember 11. 2.

18 Kürti Menyhért (1875-1949) ciszterci szerzetes, tanár, irodalomtörténész.

19 Uo. 1925. október 25. 1.

20 Uo. 1925. december 13. 1. 
keretében. A rendezvény programja a következo volt: „1. Elnöki megnyitó, mondja Trak Géza polgármester 2. "Esterházy és a müvészet irta Szmrecsányi Miklós nyugalmazott miniszteri tanácsos, a Gárdonyi Társaság tiszteletbeli tagja 3. "Ünnepi óda"i irta és felolvassa vitéz Veszprémy Dezsö leánygimnáziumi igazgató, a Gárdonyi Társaság rendes tagja 4. "Esterházy Károly grófés Eger", tartja Breznay Imre címzetes tanitóképzöi igazgató, a Gárdonyi Társaság alelnöke 5. Esetleges inditványok." ${ }^{21}$ A szereplők a korabeli Eger kulturális életének ismert és meghatározó szereplői voltak.

A tudósítás szerint „a török pusztitás után romjaiból fönixmadárként újjáéledö Eger történelmének müemlékei elevenedtek meg a városházán". ${ }^{22} \mathrm{Az}$ ünnep fénye és színvonala azonban inkább az 1925. évben járó Egerhez volt méltó mint egy 18. századi mecénás érdemeihez. Aznap vasárnap délelőtt a városháza díszterme zsúfolásig megtelt az ünneplő közönséggel, amelynek soraiban helyet foglalt Szmrecsányi Lajos érsek, Isaák Gyula, Heves vármegye főispánja, Okolicsányi Imre alispán, a fókáptalan összes tagja és az egri helyőrség tisztikarának küldöttsége, valamint Eger intelligenciájának egy része. Trak Géza ${ }^{23}$ polgármester fennkölt ünnepi beszéddel nyitotta meg az öszszejövetelt. Hosszasan méltatta a 200 éve született püspök érdemeit, és hangsúlyozta, hogy Eger a „magyar Athén” nevet kizárólag Eszterházy Károlynak köszönheti. ${ }^{24}$

Ezután Kálnoky István városi főjegyző felolvasta az üdvözlő táviratokat. Elsőként Pápát a „püspök szülővárosának” említette, ami azonban súlyos tévedés volt, mert az a város papi tevékenységének és jótékonyságának volt első helyszíne. A fóként református értelmiségiekből álló nagykőrösi Arany János Társaság köszöntése inkább a Gárdonyi Társaságnak szólt, a Műemlékek Országos Bizottsága és Wälder Gyula műegyetemi tanár táviratai pedig a kulturális együttműködésnek voltak köszönhetők. Ezek alapján úgy tűnik, hogy valóban szükség volt arra, hogy minél jobban és minél többen megismerjék a püspök életét és valódi tevékenységét.

A következőkben Kriston Endre ${ }^{25}$ püspök, a társaság tiszteletbeli tagja vezette be Szmrecsányi Miklós „Esterházy és a müvészet” címü tanulmányát, amelyet a neves művészettörténész betegsége miatt ő maga olvasott fel. Írása olyan hosszú, részletes és szakszerü volt, hogy később önállóan is megjelent, ${ }^{26}$ bár a helyi lap meglehetősen részletesen ismertette. Így az érsek fivére nagyon alapos és széles körű képet

21 Uo. 1925. december 6. 3.

22 Uo. 1925. december 15. 1.

23 Trak Géza (1877-1936) 1924-től Eger polgármestere.

24 Elnöki megnyitó, Írta s Eger városának 1925. évi dec. 13-án tartott díszközgyűlésén elmondta Trak Géza polgármester. In: Galanthai Gróf Esterházy Károly egri püspök emlékének ünneplése születésének kétszázados évfordulója alakalmából Eger város közönségének 1925. évi december hó 13-án tartott díszközgyülésén. Érseki Liceum Könyvnyomdája, Eger 1926. 3.

25 Kriston Endre (1877-1960) római katolikus pap, nagyprépost, címzetes püspök, egyházi író, a felsőház tagja.

26 Szmrecsányi Miklós: Esterházy és művészet. In: Galanthai Gróf Esterházy Károly egri püspök 
adott a püspökrőll. ${ }^{27}$ Leszögezte, hogy a Hatvani II. és III. negyed a 18. század második felében „virágzó müvésztelep” volt, amelyet a püspök iránti szeretetből „Új Károlyvárosnak" (Nova Civitas Carolina) neveztek el, de ma már inkább Károlyújváros lenne a pontosabb neve. A művészettörténész szerint - nagy túlzással - talán ez volt az első művészkolónia az országban, mivel építészek, festők, szobrászok, és mesteremberek „egész serege" élt és dolgozott itt. ${ }^{28}$

Szmrecsányi Miklós ugyanis már másfél évvel korábban kifejtette, hogy Eszterházy püspök sok festőt, szobrászt és díszítőművészt hívott Egerbe. Elhelyezésük kérdése adott okot arra, hogy egy új városrész kialakításával foglalkozzon. A művészettörténész szerint Eger ezért neki köszönheti, hogy létrejött a Hatvani városrész, melyet a Vörösmarty és Baktai út középen szel át, azokat pedig széles utcák keresztezik. Ez a szerencsésen megválasztott magas fekvésủ városrész a szerzetesi naplókban állandóan a „Nova Civitas Carolina” néven fordult elő a nagy vásártérrel együtt, melyet Eszterházy szintén a városnak ajándékozott és Károly térnek nevezték. Szmrecsányi egyébként meg volt győződve, hogy Johann Lucas Kracker festőművész házát is azon a tájon, a későbbi Károlyvárosban kellett keresni. ${ }^{29}$ Végül emlékeztett, hogy amikor a nagy püspök 1799-ben meghalt, végrendeletében a Líceumot nevezte meg általános örököséül. A művészettörténész is támogatta, hogy az érsek és fôkáptalan a Líceumot régi díszében állíttassa helyre.

Kriston felolvasása után vitéz Veszprémy Dezső ${ }^{30}$, az angolkisasszonyok leánygimnáziumának igazgatója saját ünnepi ódáját olvasta fel, majd Breznay Imre ${ }^{31}$ tanítóképző-intézeti címzetes igazgató, a Gárdonyi Társaság alelnöke mondta el ünnepi beszédét, melyben Eszterházy munkásságát Eger város fejlődése szempontjából ismertette részletesen. Egy-két számadattal mutatta be, milyen hatással volt a város életére a nagy püspök tevékenysége. Felidézte, hogy az 1699. évi összeírás szerint 42 gazda, 90 zsellér és 120 kézműves család élt Egerben, 412 lakott és 468 lakatlan ház volt a városban. Még 1720-ban is mindössze 2500 lakosa volt Egernek, 1821-ben viszont már 17 ezer. Következtetése így hangzott: „A nagy püspök tehát annyira felvirágoztatta Eger gazdasági életét, iparát és kereskedelmét, hogy itt jólétben, boldogságban élt a polgárság és új telepedésekkel megszaporodtak Eger lakói. "32

emlékének ünneplése születésének kétszázados évfordulója alakalmából Eger város közönségének 1925. évi december hó 13-án tartott díszközgyülésén. Érseki Liceum Könyvnyomdája, Eger 1926. 5-50.

27 Egri Népújság, 1925. december 15. 1.

28 Szmrecsányi M.: Esterházy és művészet i. m. 17.

29 Uö: Hol volt Krackernek, az egri nagy művésznek, háza és müterme? Egri Népújság, 1924. március 27. 2.

30 Veszprémy Dezső (1878-?) középiskolai tanár, egri leánygimnáziumi igazgató.

31 Breznay Imre (1870-1944) egri tanár, újságíró, helytörténész.

32 Egri Népújság, 1925. december 15. 2. 
Ezután a közgyülés Trak Géza polgármester indítványára elhatározta, hogy a magyar katolikus egyház egyik vezéralakja iránt érzett kegyeletből és hálából az egri Hatvani II. és III. városnegyedeket ezentúl ismét Károlyvárosnak nevezik el. A résztvevők határozatot hoztak, hogy ebből a célból átiratot intéznek a városi közgyűléshez. Befejezésül a polgármester záró szavaival köszönetet mondott az ünnepség előadóinak és a Gárdonyi Társaságnak. ${ }^{33}$

A közgyülés 1926. március 27-én tartott ülésén került napirendre újra Eszterházy püspök emlékezete. Dr. Kálnoky István bemutatta a gróf Eszterházy Károly egri püspök születésének 200. évfordulója alkalmából rendezett ünnepi ülés jegyzőkönyvét, és a közgyűlés egyhangú lelkesedéssel elhatározta, hogy az elhangzott beszédeket teljes szövegükben kinyomtatja és szétosztja a képviselőtestület tagjai között. Egyúttal elhatározták, hogy a nagynevű egri püspök emlékére a régi Károlyváros elnevezést ismét felújítják, s a Hatvani III. negyedet Alsó Károlyvárosnak, a Hatvani IV. negyedet pedig Felsö Károlyvárosnak nevezik el. ${ }^{34}$

Eszterházy püspök 1926-ban még egyszer „egri csillag” lett Angyal Lajos felső kereskedelmi iskolai tanár Üstökösjáráskor címủ írásában. A szerző kritikus hangon tekintett vissza egyéb felületes országos ünnepségekre, ugyanakkor határozott tanulságokat fogalmazott meg az igazi és gyakorlati tisztelet megvalósításához. Felidézte, hogy 100 éve annak, hogy Széchenyi István 1825-ben egy nagyszerü gesztussal megvetette az alapját a Magyar Tudományos Akadémiának, Eger városa pedig Eszterházy Károly 200 éves emlékének áldozott. „Üstökösök járnak a magyar égbolton - hangzott az összehasonlítás - s nyomukban megelevenednek nemzeti nagy létünk legragyogóbb fejezetei, az áldozatos honszerelem ragyogó példái. ${ }^{\prime 35} \mathrm{Az}$ ünnepi szónokok a Széchenyi és Eszterházy inkarnációját ünnepelték, és súlyos, szép gondolatok keltek szárnyra, de Angyal tanár úrnak úgy tűnt, hogy csak szalmaláng jellegüek voltak a megemlékezések, és csak néhány hétig élt az újjászületés reménye, az áldozatkészség ígérete, később kényelemszeretetből lelohadt a nagy lelkesedés.

Angyal különös módon kapcsolta össze az egri barokk föpap kultuszát az 1925. november közepén statáriális bíróság elé állított kommunisták, Rákosi Mátyás és társainak perével. „A Széchenyi-, Esterházy-ünnepségeinken kitörö lelkesedéssel ünnepeljük a magyar géniusz újjászületését... és ugyanakkor az egyik törvényszéki tárgyaláson fölényes nyugalommal számolnak be a vádlottak arról, miként akarták a kommunizmus feltámasztásával nemzetünk sirját megásni. ${ }^{\text {"36 }}$ Eszerint nem elég megidézni a nagy magyarok szellemét, hanem szorgalmasan dolgozni kell példamutatásuk alapján,

33 Uo.

34 Uo. 1926. március 30. 1.

35 Uo. 1925. december 18. 1.

36 Uo. 
mert mások - a kommunisták - fogják ellopni a nemzet jövőjét. Megcsodáljuk a "magyar géniusz gyönyörü ragyogását", folytatódik a figyelmeztetés, de az alkotómunka már nem kenyerünk, mert kényelmünket kellene érte feláldoznunk.

A szerző következtetése és a programja viszont korszerủ és pozitív volt. Nagyjaink tiszteletének az lesz az igazi megtestesülése, ha az ő fényüknél ráeszmélünk saját lustaságunkra, „patópálságunkra” - írta. Hőseink követése pedig csak akkor biztathat győzelemmel, ha a társadalom vezetői és az értelmiség képviselöi őszinte szeretettel nyúlnak a teljesen elhanyagolt, magára hagyatott néptömegek után, úgyhogy azok maguk is a magasba kívánkozzanak. Másrészt nagyvonalú, a haladó kor kívánalmaihoz mért szociális reformokkal kell biztosítani a magyar erkölcs és ezzel az egész magyar élet felemelkedését, és oly páncéllal kell felövezni a nemzetet, amelyről minden "pokoli tévtan”, pl. a kommunizmus is visszapattan. Tulajdonképpen arra a szociális érzékenységre emlékeztette olvasóit, amely Széchenyit és Eszterházyt egyaránt jellemezte, és azt fogalmazta meg, hogy nagyjainknak az az igazi kultusza, ha önfeláldozóan követjük és folytatjuk társadalmi és kulturális tevékenységüket. Ennek az óvatos figyelmeztetésnek bizonyára Egerben is megvoltak az okai. Szmrecsányi Lajos érsek egyébként nagyon sok téren követte is Eszterházy püspök útját akár a kultúra pártfogójaként, akár egy új városrész alapítójaként. „Üstökösök járása gyújt fényt a magyar éjszakába - fejezte be gondolatmenetét a szerző. - Üstökösök fénye világitsa meg a magyar elméket, hogy elérkezhessél a várva várt hajnal, a nagy kibontakozás: a magyar feltámadás?' ${ }^{37}$ Csillagászati kifejezésekkel szólva viszont éppen nem hullócsillagokra - ideiglenes vezérekre -, hanem folyamatosan és erősen világító állócsillagokra - örök példaképekre - van szükség, de Eszterházy püspök ennek a követelménynek is eleget tett.

\section{A cserkészek emlékezése}

Az egri római katolikus fiú felső kereskedelmi iskola 1921-ben nyílt meg az érsek és a fökáptalan segítségével keresztény szellemü kereskedelmi alkalmazottak nevelése érdekében. A tanulók tanáraik vezetésével néhány évvel később már önálló cserkészcsapatot alakítottak, amely a számozás szerint a harmadik volt Egerben, és egyes források szerint először Balassi Bálint nevét vette fel. ${ }^{38}$ 1925-ben azonban már Eszterházy-cserkészeknek hívták őket, és mivel az iskolában szegényebb családokból származó gyermekek tanultak, a nyári cserkésztábor megszervezése is anyagi

37 Uo.

38 Uo. 1924. december 11. 2. 
nehézségekbe ütközött. Talán ezért gondolták azt, hogy inkább a legendás püspök nevét vennék fel, mert egyrészt az általa építtetett Líceum II. emeletén voltak tantermeik, másrészt pedig ezzel a névvel a bicentenárium évében könnyebben kaphatnak támogatást nyári programjaikra. 1925 tavaszán kiderült, hogy erre a célra dr. Ambrus István ${ }^{39}$ kanonok, a teológia és a jogakadémia igazgatója adta az első 1 millió koronát még 1924 őszén. Az 1925-ös megemlékezések kezdetekor a kéksapkás kereskedelmis diákok már lelkesen készültek a nyári táborozásra. ${ }^{40}$

Hamarosan megjött Budapestről a névváltoztatásról szóló hivatalos levél is. A Magyar Cserkészszövetség 1925. április 28-án kelt 426. sz. engedélyével hozzájárult, hogy az egri fiú felső kereskedelmi iskola Balassi Bálint cserkészcsapata nevét 294. sz. Esterházy Károly Cserkészcsapatra változtassa ${ }^{41}$ A fiúk Szmrecsányi érsektöl, Kriston püspöktől és a káptalantól is jelentős összeget kaphattak, mert július elején már a káptalan Egyek melletti Saruka ${ }^{42}$ nevü birtokáról küldtek köszönőlevelet az érseknek, visszaérkezésük után pedig Lénárt János parancsnok, dr. Temesváry István és Szokolovszky Béla tanárok, cserkésztisztek vezetésével személyesen is tisztelegtek az érseknél megköszönve segítségét, amely lehetővé tette a nyári táborozást. ${ }^{43}$

Az Eszterházy-cserkészek azonban a tábor után sem tétlenkedtek, és újabb kezdeményezéssel járultak hozzá névadójuk örökségének ápolásához. Az Egerért címủ tudósítás szerint bizonyítani akarták, hogy készek tevékenyen ápolni a püspök emlékét, és folytatni akarják annak kulturális misszióját. Nem elégedtek meg az egyéni kötelességek teljesítésével, hanem közös munkával akartak felkészülni a jövő nagy feladataira. Bármilyen kis feladatot el akartak vállalni, ha úgy látták, hogy azzal a haza javát és a jövőt szolgálják, ezért rengeteg teendőjük volt. A tudósító felidézte, hogy az idő milyen pusztítást vitt végbe Egerben és főleg annak legfőbb díszében és legnagyobb műemlékében, a várban, amit annak idején Mária Terézia 7000 forintért adott el Eszterházy Károly püspöknek. A dicső erődítmény az építkező püspökök és érsekek kőbányája lett, így a vár köveit megtalálhatjuk többek között a Líceum falaiban is. 1783-ban Eszterházy püspök a közben ismét kincstári tulajdonba került várat 10778 forintért végleg megvette a császártól. "Ha nincs vár és nem lett volna dicsö védöje Dobó, Eger éppoly szintelen városka volna az országban mint a többi. Es mégis ki törödik a várral, mi lett belöle, micsoda

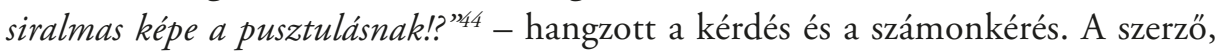
aki a kereskedelmi iskola tanára lehetett, elismerte, hogy a vár fenntartása nehéz

39 Ambrus István (1860-1935) egri teológiai tanár, kanonok.

40 Uo. 1925. március 14. 3.

41 Uo. 1925. május 8. 2.

42 Saruka külterületi település Egyektől északnyugatra a Tisza közelében.

43 Uo. 1925. július 19. 3.

44 Uo. 1925. július 29. 1. 
és költséges feladat, pénz pedig nincs, de voltak, akik mégis úgy gondolták, hogy a vár egy kis áldozattal nem a kiadási, hanem a bevételi rovatban fog szerepelni. A földalatti folyosólabirintust ugyanis a mérnökök megvizsgálták, és boltozatait épnek találták. „Magyarország tanuló iffúsága, történelmi emlékeink barátai, a rendkivüliséget keresök mind figyelmükre fogják méltatni, ha (a vár) könnyebben hozzáférhetö és veszély nélkül megtekinthetö lesz." ${ }^{\text {‘5 }}$ - hangzott a később beteljesült jóslat 92 évvel ezelött.

Az Eszterházy-cserkészek és tisztjeik kértek engedélyt először az egri laktanya parancsnokától, hogy a várban található Bolyki-bástyából kiinduló folyosórendszert kitisztítsák, mivel a romos építmény a honvédség tulajdona volt. 1925-ben még a mai Zárkándy-bástyát tartották a Bolyky-bástyának, de éppen az ekkor kezdődő kutatás tisztázta a vár egyes részeinek pontos helyét. ${ }^{46}$ Schrantz Ödön ezredes Eger katonai állomásparancsnoka lelkesen felkarolta és hivatalos engedélyével is segítette elképzelésüket. A cserkészek terve volt az is, hogy a kazamata megtekintésért belépődíjat fognak szedni és az így befolyt összeget a vár fokozatos restaurálására fogják fordítani.

Az egri vár felújítási munkája 1925. július 26-án reggel szerény keretek között indult meg. A tudósítás szerint az Eszterházy-csapatot a többi egri cserkész is készségesen fogja támogatni, és a várban végzett munkát be fogják illeszteni a rendes cserkészfeladatok keretébe. A cserkészek munkájával, valamint a város, a megye, az ország közérdeklődésének és áldozatkészségének segítségével évről évre a vár más és más részlete fog a pusztulástól megmenekedni - olvashatjuk a terveket, és a tudósító tulajdonképpen a mára már megvalósult álmokat foglalta össze. „A vár mint rom, költség, a restaurált vár ellenben egy oly bevétel forrását fogja jelenteni a városnak és annak polgárainak az idegenforgalom növekedése révén, mely egyelöre felbecsülhetetlen. Régi kutatók feljegyzései szerint bámulatos felfedezésekre lehet számitani a helyreállitás kapcsán, melyek a közérdeklödés megfelelö országos felkeltése mellett országos segélyforrásokat is meg fognak nyitni Egerért. ${ }^{\text {"37 }}$ A 294. sz. Eszterházy Károly Cserkészcsapat kérésére Eger város tanácsa is foglalkozott azzal a kérdéssel, hogy milyen formában támogathatná a vár restaurálására megindult akciót. A tanács Braun Károly fójegyző előterjesztésére 1500000 koronát utalt ki a halaszthatatlan beszerzésekre, és egy kaput ajándékozott a csapatnak, hogy a kazamaták lejárata elzárható és így a további szennyezés megakadályozható legyen. Azonkívül a város a mérnöki hivatallal való előzetes megbeszélés feltétele mellett ingyenes sankszedést, vagyis üledékszállítást engedélyezett. A városi tanács gyors és előzékeny intézkedését az „egri vár barátai” köszönettel fogadták, és

45 Uo.

46 Lénárt Andor: Az egri vár feltárásának története 1949-ig. Studia Agriensis 2. Eger 1982. 127.

47 Egri Népújság, 1925. július 29. 1. 
remélték, hogy mások is követik a nemes példát. ${ }^{48} \mathrm{~A}$ munkát ezután három tanár irányította: a kezdeményező Lénárt János, valamint dr. Pálos Ervin és dr. Pataki Vidor szerzetesek. ${ }^{49}$ Ök kértek engedélyt korábban is a helyőrség parancsnokságtól a munkához, és a honvédelmi miniszter végül 1925. július végén engedte meg a vár helyreállítását korlátozott feltételekkel és csak a cserkészek céljaira. ${ }^{50}$

1925. szeptember elejére a felújítás első lépései sikeresen befejeződtek, majd az eredményt megmutatták a közvéleménynek, amit a helyi lap így hirdetett: „ $A z$ egri vár kazamatái megtekinthetök. Az eddig feltárt részek minden szombaton délután 4 és 6 óra, és minden vasárnap délelött 10 és 1 óra között megtekinthetök. Feljárat a Bolyki-bástya ${ }^{51}$ északkeleti sarkán. Az alagút kapuja a bástya közepén a sinek mellett van. Belépödij dij felnötteknek 10.000 korona, diákoknak 5000 korona. ${ }^{52}$ Délután 4 órakor és délelött 11-kor a nagyobb csoportok vezetöt kapnak. Világitó eszközöket a látogatók hozzanak magukkal." ${ }_{33}$

1925-ben az Eszterházy Károly Cserkészcsapat diákjai és tanárai kétszeresen is méltóak voltak névadójukhoz. Egyrészt elkezdték annak a várnak a megóvását, amelyet a püspök vásárolt meg „kőbánya” céljából a Líceum építéséhez, másrészt közvetlen fizikai munkájukkal őt követték, az ő kultuszát szolgálták Eger kulturális örökségének megóvásában és továbbfejlesztésében.

48 Uo. 1925. augusztus 2.3.

49 Pálosi Ervin és Pataki Vidor szerzetesek 1925-ben az egri ciszterci gimnázium tanárai voltak.

50 Lénárt A.: Az egri vár feltárásának története 1949-ig i. m. 21.

51 Ma Zárkándy-bástya.

521925 szeptemberében 5000 korona volt az egri piacon 1 liter fejtett bab vagy $1 \mathrm{~kg}$ alma, ami 1925 novemberében már 10000 korona lett.

53 Egri Népújság, 1925. szeptember 26. 3. 


\section{The Commemoration of Bishop Károly Eszterházy in Eger in 1925}

On $4^{\text {th }}$ May 1925 - the $200^{\text {th }}$ anniversary of Bishop Károly Eszterházy's birth -the assembly of the clergy of Eger was held, where Archbishop Lajos Szmrecsányi gave a lecture about the life and work of his predecessor, then he went on to announce the renovation of the building of the Lyceum, that had been damaged in an earthquake.

Gyula Wälder, an architect from Budapest oversaw the reconstruction works. His influence helped the Eger representatives of the so called neo-baroque culture and Christian-nationalist ideology find their ideal in bishop Eszterházy, and his original contemporary baroque institutes. The reconstruction ended in 1929 by placing a plaque in the hall of the Lyceum.

In December, 1925, the Gárdonyi Géza Literature Society invited applications for writing a historical biography on Bishop Eszterházy, and there was a ceremonial public general meeting in the town hall, where art historian Miklós Szmrecsányi and two teachers, Dezső Veszprémy and Imre Breznay, commemorated the bishop and his time. The next year, the general assembly of Eger renamed a neighbourhood given to the town by Bishop Eszterházy to "Károlyváros", meaning "Károly’s Town".

In 1925, the 294 ${ }^{\text {th }}$ Eszterházy Károly Boys Scout Troop was re-established in a boys' middle school of commerce. Later that year the scouts and their teachers cleaned out one of the casemates in the Castle of Eger and prepared it for boy scout meetings and also for tourist visits.

\section{Jágerská pamät na Karola Eszterházyho v roku 1925}

4. mája 1925 sa na 200. výročie narodenia Karola Eszterházyho konala v Jágri arcidiecézna synoda. Arcibiskup Lajos Szmrecsányi venoval svoj dlhý príhovor životnej dráhe svojho vzdialeného predchodcu. Zároveň prehlásil svoj zámer opravit budovu Lýcea poškodenú zemetrasením. Obnovovacie práce prebiehali pod vedením univerzitného profesora Gyulu Wäldera. Pod jeho vplyvom našla miestna, tzv. neobaroková kultúra a krestansko-národná ideológia svoj vzor v pôvodnom barokovom pôsobení Karola Eszterházyho. Obnovovacie práce sa skončili v roku 1929 odhalením pamätnej tabule v predsieni Lýcea. V decembri 1925 vydal Literárny spolok Gézu Gárdonyiho výzvu na napísanie Eszterházyho životopisu a spolu s mestskou radou si uctili jeho pamiatku na slávnostnom zasadnutí. Pri tejto príležitosti odzneli príspevky Miklósa Szmrecsányiho, Dezső Veszprémyho a 
Imre Breznayho. V roku 1926 bola jedna z mestských štvrtí opät premenovaná na Karolovo mesto (Károlyváros). Dielo a obetavost́ vel'kého biskupa si pripomenuli aj členovia 294. Skautského oddielu Karola Eszterházyho, pôsobiaceho pri miestnom štátnom reálnom gymnáziu. Pod vedením svojich učitel'ov vyčistili a od septembra 1925 turisticky sprístupnili jednu z hradných kazamát. 